\title{
Eksistensi Hukum Islam Di Indonesia \\ (Analisis Kontribusi dan Pembaruan Hukum Islam Pra dan Pasca Kemerdekaan \\ Republik Indonesia)
}

\author{
Dahlia Haliah Ma’u (lystia.lia@gmail.com) \\ Institut Agama Islam Negeri Pontianak, Kalimantan Barat, Indonesia
}

\begin{abstract}
The implementation of Islamic law in Indonesia is closely related to the early arrival of Islam in Indonesia. It means that after the entry of Islamic into Indonesia, Islamic law has been followed and executed by the followers of Islam in archipelago. The existence of Islamic law that is lives in the society is recognized by the Dutch Colonial. The Dutch government realized that Islamic law is one of the pillars of power that can fight against on Dutch policy. On this basis, the Dutch changed their policy by stipulating that Islamic law applies if it has been adopted by common law. The struggle of Islamic law of Indonesia to change these policies to obtain that common law is not in accordance with Islamic law will not be applied or refused by Muslim. Furthermore, post-independence, the existence of Islamic law is progressing. This is marked by the enactment of legal product by the government and has become a positive law in Indonesia.
\end{abstract}

Keywords: Islamic law, Existence, Legislation, Ijtihad

\begin{abstract}
ABSTRAK
Penerapan hukum Islam di Indonesia berkaitan erat dengan awal masuknya Islam di Indonesia. Artinya, setelah masuknya Islam ke Indonesia, hukum Islam telah diikuti dan dilaksanakan oleh para pemeluk agama Islam di Nusantara ini. Eksistensi hukum Islam yang hidup di kalangan masyarakat diakui oleh pihak kolonial Belanda. Pemerintah Belanda menyadari bahwa hukum Islam adalah salah satu pilar kekuatan yang dapat melakukan perlawanan atas kebijakan politik Belanda. Atas dasar ini, pihak Belanda merubah kebijakannya dengan menetapkan bahwa hukum Islam berlaku jika telah diadopsi oleh
\end{abstract}


hukum adat. Perjuangan Pemikir hukum Islam Indonesia untuk merubah kebijakan tersebut membuahkan hasil bahwa hukum adat yang tidak sesuai dengan hukum Islam tidak akan diterapkan atau ditolak oleh umat Islam.Selanjutnya, pasca kemerdekaan, eksistensi hukum Islam mengalami kemajuan. Hal ini ditandai dengan pemberlakuan produk hukum oleh pemerintah dan telah menjadi hukum positif di Indonesia.

Kata Kunci: Hukum Islam, Eksistensi, Legislasi, Ijtihad. 


\section{PENDAHULUAN}

Indonesia $^{1}$ adalah salah satu negara yang secara konstitusional tidak menyatakan diri sebagai negara Islam, tetapi mayoritas penduduknya menganut agama Islam. ${ }^{2}$ Sebagian hukum Islam telah berlaku di Nusantara sejak zaman kerajaan-kerajaan Islam. Adanya Peradilan Agama dalam Papakeum (kitab) Cirebon merupakan salah satu bukti. Demikian pula, kerajaan Sultan di Aceh, kerajaan Pasai, Pagar Ruyung dengan Dang Tuanku Bundo Kanduang, Padri dengan Imam Bonjol (Minangkabau), Demak, Pajang, Mataram, bahkan juga Malaka dan Brunei Semenanjung Melayu (Ramulyo, 1985: 53).

Islam sebagai agama mayoritas bangsa Indonesia mempengaruhi pandangan hidup bangsa ini sepanjang sejarah, termasuk dalam bidang hukum. Kenyataan ini dilihat oleh para ahli hukum Belanda sendiri sehingga mendorong Lodewijk Willem Christian Van den Berg (1845-1927) dan kawan-kawan memperkenalkan teori receptio in complexu ${ }^{3}$ bahwa hukum mengikuti agama yang dianut seseorang. Artinya, bagi orang Islam Indonesia, hukum Islamlah yang berlaku baginya, sekalipun terdapat keragaman dalam praktiknya. Keadaan ini berlaku lebih dari satu abad, sampai datangnya ahli hukum adat dari Belanda antara lain Snouck Hurgronje (1875-1936) dan Cornelis Van Vollenhoven (1874-1933) yang memperkenalkan teori receptie (resepsi).

Menurut Hurgronje dan Van Vollenhoven, hukum yang hidup dalam masyarakat Indonesia bukan hukum Islam tetapi hukum adat yang diwarisi secara turun temurun. Bahkan menurut Hurgronje, hukum Islam baru berlaku setelah diterima (diresepsi) oleh hukum adat dan menjadi hukum adat dan bukan hukum Islam (Dahlan et.al, 1996: 967). Berdasarkan penyelidikan Hurgronje terhadap orang-orang Aceh dan Gayo di Banda Aceh,bahwa yang berlaku bagi orang Islam di kedua daerah tersebut bukanlah hukum Islam, tetapi hukum adat.

\footnotetext{
${ }^{1}$ Indonesia merupakan negara kepulauan yang berpenduduk mayoritas muslim, terletak di Asia Tenggara, antara Benua Asia dan Benua Australia, dan merupakan negara berpenduduk muslim terbesar di dunia. Negara ini merdeka tanggal 17 Agustus 1945, dari penjajahan Jepang yang berlangsung selama tiga setengah tahun (1942-1945), sebelumnya negara ini dijajah Belanda (Dahlan et.al, 1996: 710).

${ }^{2}$ Berdasarkan data Badan Pusat Statistik (BPS)tahun 2010 bahwa dari 238 juta jiwa penduduk Indonesia, penganut agama Islam mencapai $87 \%$ atau sekitar 207 juta jiwa.

${ }^{3}$ Assaad (2014) menjelaskan bahwa materi teori receptio in complexu dimuat dalam pasal 75 ayat 3 RR (Regeering Reglement) tahun 1855 yaitu: oleh hakim Indonesia itu hendaklah diberlakukan undang-undang agama (godsdienstige wetten) dan kebiasaan penduduk Indonesia. Jadi, pada masa teori ini hukum Islam berlaku bagi orang Islam.
} 
Dalam hukum adat itu memang telah masuk pengaruh hukum Islam, tetapi pengaruh itu baru mempunyai kekuatan hukum kalau telah benar-benar diterima oleh hukum adat (Ali, 1990: 219).

Teori di atas (teori receptie), mendapat kritikan dari para pemikir hukum Islam di Indonesia. Salah satu tokoh yang berani menantang teori tersebut adalah Hazairin (19051975), ahli hukum adat dan hukum Islam terkemuka dari Fakultas Hukum Universitas Indonesia. Ia mengemukakan, teori tersebut merintangi kemajuan Islam di Indonesia, itu adalah teori iblis karena mengajak orang Islam untuk tidak mematuhi dan melaksanakan perintah Allah dan sunnah Rasul-Nya (Ali, 1990: 220). Hazairin lalu menyatakan teorinya bahwa hukum adat baru berlaku kalau tidak bertentangan dengan hukum Islam. Artinya, hukum adat yang tidak sejalan dengan hukum Islam harus dikeluarkan, dilawan atau ditolak. Teori ini dikenal dengan teori receptie exit atau receptie a contrario (Rofiq, 2000: 21).

Seiring dengan beragamnya corak pemikiran teori hukum di atas serta perkembangan dinamika pemikiran dan penerapan hukum Islam di Indonesia (dari masa pra kemerdekaan sampai pasca kemerdekaan), maka muncullah teori eksistensi yakni teori yang menerangkan tentang adanya hukum Islam dalam hukum nasional Indonesia. Menurut teori ini, bentuk eksistensi (keberadaan) hukum Islam dalam hukum nasional adalah: 1) hukum Islam adalah bagian integral dari hukum nasional Indonesia. 2) hukum Islam bersifat mandiri, dalam arti kekuatan dan wibawanya diakui oleh hukum nasional dan diberi status sebagai hukum nasional. 3) norma hukum Islam (agama) berfungsi sebagai penyaring bahan-bahan hukum nasional Indonesia. 4). Hukum Islam merupakan bahan dan unsur utama hukum nasional Indonesia (Dahlan et.al, 1996: 713). ${ }^{4}$

Merujuk pada latar belakang, maka tulisan ini mendeskripsikan tentang eksistensi hukum Islam di Indonesia yang dituangkan melalui produk hukum berupa perundangundangan yang bernuansa hukum Islam dengan formathukum Islam yang cecara formil maupun materil ditransformasikan melalui sumber persuasif dan otoritatif (persuasive and

${ }^{4}$ Paparan tentang teori eksistensi dapat dibaca juga dalam tulisan Assaad (2014). 
authoritative source). Tulisan ini juga mengungkap upaya pembaruan hukum Islam di Indonesia.

\section{METODE PENELITIAN}

Penelitian ini termasuk dalam lingkup jenis penelitian kepustakaan (library research) dengan menggunakan analisis data induksi-interpretasi dan konseptualisasi. Penulis menggunakan penelitian kepustakaan karena sumber primer yang dijadikan rujukan berupa bahan-bahan tulisan berupa produk hukum di Indonesia. Disamping itu, tulisan ini juga menggunakan pendekatan normatif - historis, karena penulis mengungkap tentang beberapa aturan normatif yang berkaitan dengan produk hukum Islam di Indonesia. Penulis juga memetakan hasil produk hukum tersebut pada masa pra kemerdekaan sampai pasca kemerdekaan. Dengan pembidangan ini, eksistensi hukum Islam di Indonesia akan mudah dipahami secara komprehensif. Selanjutnya kajian ini bersifat deskriptif dan penyajian datanya secara kualitatif.

\section{KRONOLOGIS HUKUM ISLAM DI INDONESIA}

Hukum Islam baru dikenal di Indonesia setelah agama Islam disebarkan di tanah air Indonesia. Belum ada kesepakatan ahli sejarah tentang awal masuknya Islam di Indonesia. Ada yang mengatakan abad ke-1 Hijriyah atau abad ke-7 Masehi, ada pula yang mengatakan abad ke-7 Hijriyah atau abad ke-13 Masehi. Walaupun para ahli sejarah berbeda mengenai awal masuknya Islam ke Indonesia, namun dapat dikatakan bahwa setelah Islam masuk keIndonesia, hukum Islam telah diikuti dan dilaksanakan oleh para pemeluk agama Islam di Nusantara ini. Hal ini dapat dilihat dari hasil karya ahli hukum Islam Indonesia. Misalnya, Miratul Thullab, Sirathal Mustaqim, Sabilal Muhtadin, Kutaragama, Sajinatul Hukum, dan lain-lain (Ali, 1990: 189).

Azra (2007: 19) memaparkan; ... Kontak paling awal antara kedua wilayah ini (Nusantara dengan Timur Tengah), khususnya berkaitan dengan perdagangan, bermula bahkan sejak masa Phunisi dan Saba. Memang, hubungan antara keduanya pada masa 
beberapa waktu sebelum kedatangan Islam dan masa awal Islam terutama merupakan hasil dari perdagangan Arab dan Persia dengan Dinasti Cina. Agaknya, kapal-kapal Arab dan Persia yang berdagang ke Cina melakukan pengembaraan pula di Nusantara jauh sebelum Islam menjadi nyata di bagian manapun di Nusantara. Lebih lanjut, paparan Azyumardi Azra (2007: 31); ... jika dalam masa sebelumnya Muslim Arab dan Persia memusatkan kegiatankegiatan mereka pada perdagangan, sebaliknya sejak menjelang akhir abad ke-12 mereka mulai memberikan perhatian khusus pada usaha-usaha penyebaran Islam di Nusantara.

Kepulauan Indonesia sudah bersentuhan dengan Islam sejak abad ke-1 Hijriyah (abad ke-7 Masehi). Proses islamisasi berlangsung damai. Pada abad ke-13 berdiri kerajaan Islam (kesultanan) pertama yaitu Samudera Pasai di ujung Utara pulau Sumatra. Setelah itu, berdiri pula kerajaan-kerajaan Islam lainnya, seperti Demak (1500), Aceh Darussalam (1514), Banten (1568), Mataram (1582), Kerajaan Gowa (abad ke-13), Ternate (abad ke-15), Tidore (abad ke-16), Pajang (abad ke-16), Cirebon (abad ke-17), dan Tallo (abad ke-17). Setelah itu, menyusul kesultanan-kesultanan; Jambi (1500), Riau (1521), Banjar (1595), Bima (1620), Palembang (1662), Kutai (abad ke-16), dan sebagainya. Pada abad ke-18, Islam sudah menyebar hampir di seluruh Indonesia. Ulama di dalam kerajaan-kerajaan Islam, disamping sebagai penasehat raja, juga duduk dalam jabatan-jabatan keagamaan yang tingkat dan namanya berbeda-beda antara satu daerah dengan daerah lainnya (Dahlan et.al, 1996: 710).

Di sisi lain, menurut Ras (1990: 118), penelusuran hukum Islam dari aspek sejarah dapat dilihat juga dari berdirinya Masjid Demak abad ke-14 sebagai masjid pertama yang bersimbol Islam. Ia menyatakan: ...Permulaan zaman Islam dalam tradisi Jawa terkait erat dengan dua peristiwa: (1). Jatuhnya benteng agama Budha yang diwakili oleh Keraton Majapahit (2). Berdirinya masjid besar di Demak sebagai pusat kerajaan Islam yang baru, tempat beribadah hari Jum'at bagi raja dan warga keraton. Pembangunan Masjid Demak terjadi pada tahun 1428 Caka (1506).

Sebenarnya pemikiran syariat (fikih, hukum Islam) sudah berkembang di Indonesia sejak awalabad ke-13. Hal ini dibuktikan oleh laporan Ibnu Batutah (w.779 H / 1377 M), pengembara muslim Afrika Utara, yang pada 746 H / 1325 M mengunjungi Samudera Pasai 
dalam perjalanan dari Delhi ke Cina. Ketika itu Samudera Pasai diperintah Sultan Malik azZahir (1297-1326), putra Sultan Malikush Shaleh (w. 1297). Ibnu Batutah menyatakan bahwa raja dan rakyat bermazhab Syafi'i (Dahlan et.al, 1996: 710).

Selanjutnya, pada awal kedatangan Belanda, eksistensi hukum Islam yang hidup di kalangan masyarakat diakui sendiri oleh ahli hukum Belanda Van den Berg, dengan menyatakan bahwa hukum yang berlaku di Indonesia adalah hukum yang sesuai dengan agama yang dipeluknya. Akan tetapi, fakta ini berubah dengan politik pemerintah kolonial Belanda yang menyadari bahwa hukum Islam adalah salah satu pilar kekuatan yang dapat melakukan perlawanan atas kebijakan politik Belanda. Oleh karena itu, atas saran ahli hukum Belanda (Hurgronje dan Van Vollenhoven) maka pihak Belanda merubah kebijakannya dengan menetapkan bahwa hukum Islam berlaku jika telah diadopsi oleh hukum adat. Kaitannya dengan hal ini, dalam pasal 134 ayat (2) Indische Staatsregeling (IS) dirumuskan: "Dalam hal terjadi perkara perdata antara sesama orang Islam akan diselesaikan oleh hakim agama Islam apabila hukum adat mereka menghendakinya dan sejauh itu tidak ditentukan lain dengan suatu ordonansi”.

Ali (1990: 223) mendeskripsikan bahwa mulai tahun 1830, setelah pemerintah Belanda menguasai kepulauan Indonesia, Pengadilan Agama yang diselenggarakan oleh para penghulu yang telah ada di Jawa sejak abad ke-16, ditempatkan di bawah pengawasan pengadilan kolonial yakni Landraad atau Pengadilan Negeri melalui ketentuan bahwa keputusan Pengadilan Agama tidak dapat dilaksanakan sebelum ketua Landraad menyatakan persetujuannya atas pelaksanaan keputusan itu dengan executiore verklaring (pernyataan dapat dijalankan).

Dukungan pemerintah Hindia-Belanda terhadap penerapan hukum Islam hanya terbatas pada bidang kekeluargaan. Sebagaimana paparan Daniel S. Lev yang dikutip oleh Rofiq (2000: 19) bahwa pada tahun 1937 dikeluarkan Stbl. No. 638 dan 639 tentang pendirian Kerapatan Qadli dan Kerapatan Qadli Besar untuk wilayah Kalimantan Selatan dengan kewenangan sebagaimana Peradilan Agama di Jawa dan Madura. Adapun Batas kekuasaan Pengadilan Agama berdasar Stbl. 1937 No. 116 adalah: 1). Perselisihan antara 
suami istri yang beragama Islam. 2). Perkara-perkara tentang: nikah, talak, rujuk, dan perceraian antara orang-orang yang beragama Islam yang memerlukan perantara hakim agama Islam. 3). Memberi keputusan perceraian. 4). Menyatakan bahwa syarat untuk jatuhnya talak yang digantungkan (taklik talak) sudah ada. 5). Perkara mahar. 6). Perkara tentang keperluan kehidupan istri yang wajib diadakan oleh suami.

Rumusan di atas menunjukkan bahwa pada masa pemerintah kolonial Belanda, perkara yang berkaitan dengan wakaf, waris, hibah, wasiat, hadhanah, sadaqah, baitul mal, yang merupakan kewenangan Peradilan Agama di rubah menjadi kewenangan peradilan umum. Dengan demikian perkara yang menjadi kompetensi Pengadilan Agama sejak 1882 dialihkan ke Pengadilan Negeri. Lebih lanjut, Pada masa pendudukan Jepang, posisi keberlakuan hukum Islam tidak berubah. Artinya, kompetensi Pengadilan Agama yang telah di atur oleh pemerintah kolonial Belanda tidak di rubah oleh pemerintah Jepang.

Pada masa awal kemerdekaan, para tokoh muslim berupaya menempatkan hukum Islam pada kedudukannya semula dan berjuang agar hukum Islam bisa eksis di wilayah Nusantara. Berkaitan dengan hal ini, Dahlan et.al (1996: 712) memaparkan: perjuangan umat Islam berlanjut hingga masa Jepang. Jepang berusaha mengakomodasi dua kekuatan; nasionalis Islam dan nasionalis sekuler. Pada masa ini didirikan Masyumi (Majelis Syura Muslimin Indonesia) yang menghimpun hampir seluruh potensi Islam. Jepang menjanjikan kemerdekaan dengan mengeluarkan Maklumat Gunseikan No. 23 / 29 April 1945, tentang pembentukan BPUPKI (Badan Penyelidik Usaha-usaha Persiapan Kemerdekaan Indonesia), yang menghasilkan rancangan UUD dan Piagam Jakarta sebagai mukadimahnya. Dalam Piagam Jakarta, pada prinsip Ketuhanan terdapatkalimat “...dengan kewajiban menjalankan syariat Islam bagi pemeluk-pemeluknya". Dengan prinsip ini umat Islam berharap dapat menjalankan syariat agamanya di dalam Indonesia merdeka.

Tujuh kata ini (...dengan kewajiban menjalankan syariat Islam bagi pemelukpemeluknya) mengimplikasikan keterikatan umat Islam dengan hukum Islam. Akan tetapi, tujuh kata tersebut dihapus setelah terjadi perdebatan antara anggota PPKI (Panitia Persiapan Kemerdekaan Indonesia). Akhirnya, pada waktu proklamasi dengan melalui kompromi dan 
menjaga keutuhan bangsa, Piagam Jakarta tidak digunakan. Selanjutnya, rumusannya menjadi "Ketuhanan Yang Maha Esa”.

Wahib (2004) menjelaskan perdebatan tentang implementasi hukum Islam terjadi pada tahun 1959. Berikut ini kutipannya (terjemahan bebas): "Perdebatan tentang implementasi syariat (hukum Islam) terjadi pada tahun 1959 pada pertemuan dewan konstituante. Tetapi perdebatan tersebut spontan dilewati ketika Presiden Indonesia; Soekarno, menetapkan Dekrit pada 5 Juli 1959 yang menyatakan bahwa Piagam Jakarta telah menginspirasi (menjiwai) seluruh rangkaian batang tubuh (kesatuan) konstitusi UUD 1945".

Gambaran di atas mengindikasikan bahwa walaupun ditiadakan jaminan eksplisit pemberlakuan hukum Islam bagi kehidupan umat Islam, akan tetapi secara implisit, isi dekrit Presiden 5 Juli 1959 yang menyatakan bahwa Piagam Jakarta menjiwai dan merupakan satu rangkaian kesatuan dengan UUD 1945, dapat memungkinkan diberlakukannya hukum Islam bagi pemeluk-pemeluknya. Atas dasar inilah semangat UUD 1945 menjadi dasar bagi eksistensi hukum di bidang keagamaan di Indonesia.

\section{KODIFIKASI DAN LEGISLASI SEBAGAI UPAYA PENGEMBANGAN HUKUM} ISLAM

HukumIslam yang berlaku di Indonesia dapat dipilah menjadi dua. Pertama; hukum Islam yang berlaku secara formal yuridis, yaitu hukum Islam yang mengatur hubungan manusia dengan manusia lainnya dan benda yang disebut hukum muamalat (perdata). Bagian ini menjadi hukum positif berdasarkan atau ditunjuk oleh peraturan perundang-undangan, seperti perkawinan, kewarisan, dan perwakafan. Kedua; hukum Islam yang bersifat normatif yang mempunyai sanksi atau padanan kemasyarakatan. Ini bisa berupa ibadah murni atau hukum pidana (Rofiq, 2000: 23).

Kodifikasi hukum Islam di Indonesia sudah ada sejak masa penjajahan. Akan tetapi status hukumnya masih berada di bawah dominasi hukum adat. Karena teori receptie (resepsi) sangat berpengaruh dalam sistem hukum masa itu. Dapat dikatakan bahwa produk hukum Islam pada masa pemerintahan Belanda telah ada yakni mengatur Peradilan Agama 
serta materi hukumnya, akan tetapi peran hukum adat mendominasi aturan tersebut. Dengan munculnya Undang-Undang nomor 1 Tahun 1974 tentang Perkawinanmaka hukum Islam menjadi sumber hukum yang langsung tanpa melalui hukum adat. Peranan para tokoh muslim cukup dominan dalam melakukan pendekatan dengan kalangan elit, sehingga Rancangan Undang-Undang Perkawinan (UUP)dapat dikodifikasikan dan menyusul kodifikasi hukum Islam lainnya.

UUP dengan peraturan pelaksanaannya (PP No.9/1979 dan PP No.10/1983) yang mengatur secara khusus perkara-perkara perkawinan dan perceraian bagi Pegawai Negeri Sipil (PNS) dan ABRI. Selanjutnya muncul lagi Undang-Undang Peradilan Agama (UU No.7/1989). Undang-undang ini pada dasarnya merupakan tuntutan dari UU No.14/1970 tentang Pokok-Pokok Kekuasaan Kehakiman yang mengakui adanya empat peradilan di Indonesia yaitu Peradilan Umum, Peradilan Agama, Peradilan Militer, dan Peradilan Tata Usaha Negara. Ke-empat peradilan tersebut memiliki kedudukan yang sama dan berwenang secara mandiri mengadili perkara-perkara yang menjadi kompetensinya. Lebih lanjut, keluarlah Instruksi Presiden RI (Inpres No.1/1991) tentang Kompilasi Hukum Islam (KHI) di bidang hukum perkawinan, kewarisan, dan perwakafan.

Adanya UUP, UU Peradilan Agama, dan KHI, sejalan dengan perjalanan sejarah UUD 1945. Menurut Ismail Sunny (1997:40-43) penerapan hukum Islam dalam negara nasional Indoneisa dapat dibagi menjadi dua periode: Pertama, periode penerimaan hukum Islam sebagai sumber persuasif (persuasive source) yaitu sumber dimana orang harus yakin menerimanya. Periode ini berlangsung dari tahun 1945 sampai 1959. Dalam hal ini, kedudukan ketentuan "kewajiban menjalankan syariat Islam bagi pemeluk-pemeluknya" yang pernah diputuskan oleh BPUPKI dapat disebut sebagai persuasive source. Kedua, periode penerimaan hukum Islam sebagai sumber otoritatif (authoritative source) yakni sumber yang mempunyai kekuatan (authority) yang harus dilaksanakan. Periode ini berlangsung dari tahun 1959 sampai sekarang.

Salim dan Azyumardi Azra (2003: 60) memaparkan: ... ada lima aturan hukum yang secara kuat dipengaruhi oleh syariat, telah dilegislasikan dalam hukum positif dimasa 
presiden Soeharto yaitu UU Perkawinan, Peraturan Wakaf, Peradilan Agama, hukum yang membolehkan beroperasinya Perbankan Islam, dan Kompilasi Hukum Islam (KHI) yang terkait dengan kodifikasi hukum keluarga dalam Islam, termasuk aturan waris. Semasa pemerintahan presiden Habibie (1998-1999) ada tambahan dua undang-undang yang mencakup Penyelenggaraan Haji dan Pengelolaan Zakat. Semua produk hukum tersebut mengakomodir unsur-unsur hukum Islam yang diterapkan tanpa harus mencantumkan referensi apapun kepada Piagam Jakarta.

Eksistensi hukum Islam patut diperhitungkan. Artinya, kontribusi hukum Islam dalam pembangunan hukum nasional telah memiliki kekuatan normatif dan kehadirannya semakin memperkuat wibawa hukum Islam di Indonesia. Rincian produk hukum tersebut dapat dilihat pada tabel berikut ini:

Tabel 1: Legislasi Hukum Islam di Indonesia

\begin{tabular}{|c|c|c|}
\hline No & Aturan Yuridis & $\begin{array}{c}\text { Peraturan Pelaksana (PP) dan } \\
\text { Perubahan dan Penambahan }\end{array}$ \\
\hline 1 & UU No. 1 / 1974: Perkawinan & PP No.9/1979 dan PP No.10/1983 \\
\hline 2 & UU No. 7 / 1989: Peradilan Agama & $\begin{array}{c}\text { Diubah/ditambah UU No.3 / 2006 } \\
\text { UU No. 50 / 2009 }\end{array}$ \\
\hline 3 & Intruksi Presiden No.1 / 1991: Kompilasi & - \\
\hline 5 & HU No. 10 / 1998: Perbankan Syari'ah & - \\
\hline 6 & UU No. 17 / 1999: Penyelenggaraan & Diubah/ditambah UU No.13 / 2008 \\
\hline 7 & UU No.38 / 1999: Pengelolaan Zakat & Diubah/ditambah UU No.23 / 2011 \\
\hline 8 & UU No. 44 / 1999: Penyelenggaraan & \\
\hline & Keistimewaan Daerah Istimewa Aceh & Prov.Daerah Istimewa Aceh \\
\hline
\end{tabular}

Eksistensi Hukum Islam Di Indonesia (Analisis Kontribusi dan Pembaruan Hukum Islam Pra dan Pasca Kemerdekaan Republik Indonesia) 


\section{$10 \quad$ UU No. 11 / 2006: Pemerintahan Aceh}

Beberapa produk hukum di atas hanya menyangkut hukum ibadah, keluarga, dan muamalah saja, tidak ada yang secara spesifik mengatur tentang hukum pidana Islam (jinayah). Walaupun hukum pidana Islam diatur dalam UU No. 11 / 2006 tentang Pemerintahan Aceh. Akan tetapi pemberlakuan aturan ini, hanya khusus diterapkan di Aceh, tidak diberlakukan secara nasional di wilayah Nusantara.

Demikian juga UU No. 44 / 1999 tentang Penyelenggaraan Keistimewaan Daerah Istimewa Aceh, menuntut implementasi syari'ah bagi masyarakat Islam dan memberi kuasa kepada pemerintah Aceh untuk membuat kebijakan dalam kehidupan beragama, adat, pendidikan, dan peran ulama.Otonomi khusus bagi Aceh memberikan izin bagi pembentukan Mahkamah Syariah yang mempunyai kuasa bukan hanya dalam masalah hukum keluarga dan harta warisan sebagaimana yang diatur oleh Pengadilan Agama, tapi juga kasus-kasus kriminal / jinayah atau pidana (Sila, 2009).

Selanjutnya, selain beberapaproduk hukum sebagaimana pada tabel diatas, terdapat juga produk hukum lainnya, yakni produk hukum dari Komisi Fatwa dan Hukum Majelis Ulama Indonesia (KFHMUI) yang menangani persoalan keagamaan dan kemasyarakatan. Pada dasarnya KFHMUI menetapkan empat macam produk keputusan yang dikeluarkan dan disampaikan baik kepada pemerintah ataupun masyarakat atau kepada keduanya: (1). Fatwa yaitu keputusan yang menyangkut persoalan agama Islam yang perlu dilaksanakan oleh pemerintah maupun masyarakat demi kepentingan bangsa (2). Nasihat yaitu keputusan yang menyangkut persoalan kemasyarakatan yang diharapkan dapat dilaksanakan oleh pemerintah dan masyarakat (3). Anjuran yaitu keputusan yang menyangkut persoalan kemasyarakatan dalam rangka mendorong pemerintah dan masyarakat untuk lebih intensif melaksanakannya, karena hal tersebut dianggap mengandung manfaat yang besar (4). Seruan yaitu keputusan yang menyangkut masalah untuk tidak dilaksanakan atau sebaliknya tidak dilaksanakan oleh pemerintah dan masyarakat.

Produk pemikiran hukum yang berbentuk perundang-undangan (sebagaimana pada tabel sebelumnya) bersifat mengikat bagi umat Islam. Akan tetapi produk yang berbentuk 
fatwa seperti produk hukum dari Komisi Fatwa dan Hukum Majelis Ulama Indonesia (KFHMUI) sifatnya kasuistik dan bersifat dinamis, sehingga tidak mengikat bagi umat Islam. Senada dengan hal ini, Rofiq (2000: 32-33) mendeskripsikan: hukum Islam dalam bentuk fatwa, seperti fatwa MUI sifatnya kasuistik, ia merupakan respons atau jawaban terhadap pertanyaan yang diajukan oleh peminta fatwa. Fatwa tidak mempunyai daya ikat, dalam arti si-peminta fatwa tidak harus mengikuti isi hukum fatwa yang diberikan kepadanya. Adapun pemikiran hukum Islam yang berbentuk perundang-undangan, bersifat mengikat dan bahkan daya ikatnya lebih luas. Dinamikanya agak lamban, karena sebagai peraturan organik, kadang tidak cukup elastis untuk mengantisipasi tuntutan waktu dan perubahan. Dengan mengambil contoh Undang-Undang Perkawinan yang di dalamnya terdapat muatan-muatan hukum Islamnya, ia mengikat semua warga masyarakat Indonesia.

\section{IJTIHAD SEBAGAI MODEL PEMBAHARUAN HUKUM ISLAM}

Pembaharuan (pembaruan, tajdid, modernisasi) dalam Islam mempunyai tujuan untuk menyesuaikan ajaran-ajaran yang terdapat dalam agama dengan ilmu pengetahuan dan falsafat modern. Tetapi perlu diingat bahwa dalam Islam ada ajaran-ajaran yang bersifat mutlak tidak dapat diubah-ubah. Yang dapat diubah hanyalah ajaran-ajaran yang tidak bersifat mutlak, yaitu penafsiran atau interpretasi dari ajaran-ajaran yang bersifat mutlak tersebut. Dengan kata lain, pembaharuan mengenai ajaran-ajaran yang bersifat mutlak tak dapat diadakan. Pembaharuan dapat dilakukan mengenai interpretasi atau penafsiran dalam aspek-aspek teologi, hukum, politik, dan seterusnya dan mengenai lembaga-lembaga (Nasution, 1985: 91-92).

John O. Voll dalam Esposito (1983: 32-37) mengidentifikasikan tiga tema tentang reinterpretasi dan pembaharuan dalam sejarah Islam. Pertama: Penerapan al-Qur'an dan Sunnah secara sempurna adalah tanggapan pembaharu terhadap krisis dan problem yang dihadapi umat Islam. Para pembaharu berpendapat, baik secara individu maupun sebagai anggota komunitas, pentingnya berpegang pada al-Qur'an dan Sunnah. Segala sesuatu yang menyimpang dari tema awal harus ditepis dengan proses tajdid dan ishlah. Kedua: Keharusan 
ijtihad adalah proses lanjutan dari tema pertama tentang penerapan al-Qur'an dan Sunnah secara sempurna. Jika al-Qur'an dan Sunnah telah memuat esensi dan sempurna bagi pedoman dan pertimbangan, maka sumber hukum yang lain tetap berguna tapi tidak wajib diikuti secara mutlak. Para pembaharu berhak melakukan pertimbangan langsung terhadap ijtihad dari al-Qur'an dan Sunnah. Dan ia tidak terkait dengan penafsiran dan gagasan yang muncul setelah Nabi dan sahabat. Ketiga: Penegasan kembali otentisitas Islam. Walaupun ijtihad merupakan hak bagi pembaharu untuk menerapkan secara tepat pesan al-Qur'an dalam situasi yang berubah, tidak perlu meminjai tradisi luar Islam untuk melengkapi prinsipprinsip Islam.

Islam mempunyai watak dinamis yang selalu mendorong adanya gerakan pembaharuan, maka sulit dipahami jika ada sementara kalangan yang hanya mencoba menekankan pentingnya budaya Barat dalam pengembangan hukum Islam kontemporer. Bahkan mereka beranggapan bahwa modifikasi hukum Islam saat ini semata-mata karena pengaruh nilai-nilai Barat. Dengan tidak mengecilkan pengaruh nilai-nilai Barat, namun harus diingat bahwa tujuan pembaruan hukum Islam bukanlah untuk mengikuti dan meniru hal-hal yang ada di Barat, tetapi lebih dimaksudkan untuk membawa umat Islam ke jalan yang sesuai dengan ajaran hukum Islam. Atas dasar ini, maka ungkapan 'kembali pada alQur'an dan Sunnah' merupakan slogan yang selalu dikumandangkan terutama oleh para kaum pembaharu dan menjadi karakteristik umum dari gerakan pembaharuan di hampir seluruh dunia, termasuk di Indonesia (Tahir, 2005).

Kaitannya dengan pembaharuan hukum Islam, Noel J. Coulson sebagaimana yang dikutip oleh Mu'alim dan Yusdani (2001: 15) menyatakan bahwa pembaruan hukum Islam menampakkan diri dalam empat bentuk, yaitu:1). Kodifikasi (pengelompokan hukum yang sejenis ke dalam kitab undang-undang) hukum Islam menjadi hukum perundang-undangan negara, yang disebut sebagai doktrin siyasah. 2). Tidak terikatnya umat Islam pada hanya satu mazhab hukum tertentu yang disebut sebagai doktrin takhayyur (seleksi) yaitu mendapat nama yang paling dominan dalam masyarakat. 3). Perkembangan hukum dalam mengantisipasi perkembangan peristiwa hukum yang baru timbul, yang disebut sebagai 
doktrin tatbiq (penerapan hukum terhadap peristiwa baru). 4). Perubahan hukum dari yang lama kepada yang baru disebut doktrin tajdid (reinterpretasi).

Pembaharuan dilakukan dalam lapangan yang menjadi garapan ijtihad. Lapangan tersebut adalah masalah-masalah atau peristiwa-peristiwa yang memerlukan penetapan hukum yang prinsip-prinsip umumnya (mabadi' 'ammah) telah ada dalam syari'at, prinsipprinsip umum dan hukum-hukum yang terinci mengenai masalah atau perkara yang mubah (Ash-Shiddieqy, 1975: 38).

Menurut Fazlur Rahman, sebagaimana yang dikutip oleh Efrinaldi (2013) Ijtihad merupakan suatu metode dalam penggalian makna dan materi hukum dengan kemaslahatan sebagai tujuannya. Dalam konteks sekarang, ijtihad dapat berarti sebagai kerja progresif untuk memperbarui aturan-aturan yang terkandung dalam teks al-Qur'an dan Sunnah agar keduanya mampu mencakupi situasi dan kondisi baru dengan memberikan suatu solusi (aturan hukum) yang baru pula.

Merujuk pada paparan di atas, dapat dikatakan bahwa konsep pembaharuan hukum Islam adalah pembaharuan hukum Islam dalam ranah yang bersifat ijtihadi. Persoalanpersoalan hukum seperti dalam bidang kekeluargaan, muamalah, kenegaraan, kekayaan, kriminalitas, dan berbagai persoalan yang berkaitan dengan hukum publik lainnya dapat mengalami perubahan sehingga diperlukan upaya ijtihad di dalamnya. Sedangkan hukum Islam dalam bidang ibadah bersifat tetap, tidak akan dipengaruhi oleh perubahan zaman, sehingga umat Islam dituntut untuk menaatinya. Dengan kata lain, terdapat hukum yang bersifat ta'aquli dan ada hukum yang bersifat ta'abudi. Atau secara substantif harus bisa dibedakan hukum Islam yang bersifat qath ' $i$ (absolut/mutlak) dan hukum Islam yang bersifat zhanni (relatif / tidak mutlak). Dengan pemetaan seperti ini, hukum Islam akan selalu bersifat fleksibel dan dinamis di sepanjang zaman.

\section{KESIMPULAN}

Berdasarkan deskripsi kajian ini dapat disimpulkan bahwa Islam sebagai agama mayoritas rakyat Indonesia mempengaruhi pandangan hidup bangsa, termasuk dalam bidang 
hukum.Penelusuran hukum Islam dari aspek sejarahdapat ditelusuri dengan berdirinya kerajaan-kerajaan Islam di Nusantara. Eksistensi hukum Islam yang hidup di kalangan masyarakat diakui sendiri oleh ahli hukum Belanda bahwa hukum yang berlaku di Indonesia adalah hukum yang sesuai dengan agama yang dipeluknya. Pada masa pemerintah HindiaBelanda penerapan hukum Islam hanya terbatas pada bidang kekeluargaan. Artinya, produk hukum Islam pada masa pemerintahan Belanda telah ada yakni mengatur Peradilan Agama serta materi hukumnya, akan tetapi peran hukum adat mendominasi aturan tersebut. Dengan munculnya Undang-Undang nomor 1 Tahun 1974 tentang Perkawinan maka hukum Islam menjadi sumber hukum yang langsung tanpa melalui hukum adat. Peranan para tokoh muslim cukup dominan dalam melakukan pendekatan dengan kalangan elit, sehingga Rancangan Undang-Undang Perkawinan (UUP) dapat dikodifikasikan dan menyusul kodifikasi hukum Islam lainnya, seperti Undang-Undang Peradilan Agama, Pengelolaan Zakat, Wakaf, Perbankan Syariah, KHI, dan lainnya. Kontribusi hukum Islam dalam pembangunan hukum nasional telah memiliki kekuatan normatif dan kehadirannya semakin memperkuat wibawa hukum Islam di Indonesia. Seiring dengan perkembangan zaman, persoalan-persoalan hukum yang dipengaruhi oleh perubahan zaman memerlukan upaya progresif berupa penemuan hukum baru melalui upaya yang bersifat ijtihadi.

\section{DAFTAR PUSTAKA}

Ali, Mohammad Daud. (1990). Asas-Asas Hukum Islam, Pengantar Ilmu Hukum dan Tata Hukum Islam di Indonesia, (Jakarta: Rajawali Pers).

Ash-Shiddieqy, M. Hasbi. (1975). Fiqh Islam, (Jakarta: Bulan Bintang).

Assaad, A.Sukmawati. (2014). Teori Pemberlakuan Hukum Islam di Indonesia. "Jurnal alAhkam STAIN Palopo" Volume IV, Nomor 2 Agustus 2014. Palopo: STAIN Palopo.

Azra, Azyumardi. (2007). Jaringan Ulama Timur Tengah dan Kepulauan Nusantara Abad XVII dan XVIII Akar Pembaruan Islam Indonesia, (Jakarta: Kencana).

Dahlan, Abdul Azis. et.al (editor). (1996). Ensiklopedi Hukum Islam, jilid 3, (Jakarta: Ichtiar Baru Van Hoeve).

Efrinaldi, (2013). Dekonstruksi Hukum Islam dan Kristalisasi di Indonesia, "Jurnal alAdalah"Volume XI, Nomor 1 Januari 2013. Lampung: IAIN Raden Intan.

Esposito, John L. (ed.), (1983). Voices of Resurgent Islam, (Oxford: Oxford University Press).

Mu'alim, Amirdan Yusdani. (2001). Konfigurasi Pemikiran Hukum Islam, (Yogyakarta: UII Press).

Nasution, Harun. (1985). Islam ditinjau dari berbagai Aspeknya, jilid 2, (Jakarta: UI Press). 
Ramulyo, M. Idris. (1985), Hukum Islam dan Peradilan Agama di Indonesia, (Jakarta: Sinar Grafika).

Ras, JJ. (1990). “Tradisi Jawa Mengenai Masuknya Islam di Indonesia”, dalam Beberapa Kajian Indonesia dan Islam, (Jakarta: INIS).

Rofiq, Ahmad. (2000).Hukum Islam di Indonesia, (Jakarta: Raja Grafindo Persada).

Salim, Arskal dan Azyumardi Azra.(2003). Negara dan Syariat dalam Perspektif Politik Hukum Indonesia. Dalam Syariat Islam Pandangan Muslim Liberal, Editor: Burhanuddin. (Jakarta: Jaringan Islam Liberal dan The Asia Foundation).

Sila, Muhammad Adlin.(2009). Book Review: Menantang Negara Sekuler: Upaya Islamisasi Hukum di Indonesia. "Studia Islamika, Indonesian Journal for Islamic Studies" Volume 16, Number 2, 2009. Jakarta: UIN Syarif Hidayatullah.

Sunny, Ismail. (1997). Tradisi dan Inovasi Keislaman di Indonesia dalam Bidang Hukum Islam. Dalam Bunga Rampai Peradilan Islam di Indonesia, (Bandung: Ulul Albab Press).

Tahir, Masnun. (2005). Dasar-Dasar Pemikiran Pembaharuan Liberalisme Hukum Islam di Indonesia. "Istinbath: Jurnal Hukum dan Ekonomi Islam" Nomor.1 Vol.3 Desember 2005. Mataram: IAIN Mataram Fakultas Syari'ah.

Wahib, Ahmad Bunyan. (2004 / 1425). Save Indonesia By and From Shari'a: A Debateon the Implementation of Shari'a. "al-Jami'ah, Journal of Islamic Studies" Volume 42, Number 2, 2004 / 1425. Yogyakarta - Indonesia: The State Islamic University (UIN) Sunan Kalijaga. 